Article

\title{
Toxicologic Evaluation for Amorphous Silica Nanoparticles: Genotoxic and Non-Genotoxic Tumor-Promoting Potential
}

\author{
Gwang-Hoon Lee ${ }^{1,2}$, Yun-Soon Kim ${ }^{3}$, Euna Kwon ${ }^{3}$, Jun-Won Yun ${ }^{4, *}$ and \\ Byeong-Cheol Kang 1,3,5,* \\ 1 Graduate School of Translational Medicine, Seoul National University College of Medicine, \\ Seoul 03080, Korea; ghl@dgmif.re.kr \\ 2 Laboratory Animal Center, Daegu-Gyeongbuk Medical Innovation Foundation, Daegu 41061, Korea \\ 3 Department of Experimental Animal Research, Biomedical Research Institute, \\ Seoul National University Hospital, Seoul 03080, Korea; gys0804@nate.com (Y.-S.K.); \\ eunakwon@snuh.org (E.K.) \\ 4 Department of Biotechnology, The Catholic University of Korea, Bucheon 14662, Korea \\ 5 Designed Animal Resource Center, Seoul National University, Pyeongchang-gun 25354, Korea \\ * Correspondence: jwyun@catholic.ac.kr (J.-W.Y.); bckang@snu.ac.kr (B.-C.K.); \\ Tel.: +82-2-2164-4830 (J.-W.Y.); +82-2-2072-0841 (B.-C.K.)
}

Received: 26 July 2020; Accepted: 27 August 2020; Published: 29 August 2020

\begin{abstract}
Amorphous silica nanoparticles $\left(\mathrm{SiO}_{2} \mathrm{NPs}\right)$ have been widely used in medicine including targeted drug/DNA delivery, cancer therapy, and enzyme immobilization. Nevertheless, $\mathrm{SiO}_{2} \mathrm{NPs}$ should be used with caution due to safety concerns associated with unique physical and chemical characteristics. The objective of this study was to determine the effects of $\mathrm{SiO}_{2} \mathrm{NPs}$ on genotoxic and non-genotoxic mechanisms associated with abnormal gap junctional intercellular communication (GJIC) in multistage carcinogenesis. The $\mathrm{SiO}_{2} \mathrm{NPs}$ exhibited negative responses in standard genotoxicity tests including the Ames test, chromosome aberration assay, and micronucleus assay. In contrast, the $\mathrm{SiO}_{2} \mathrm{NPs}$ significantly induced DNA breakage in comet assay. Meanwhile, $\mathrm{SiO}_{2} \mathrm{NPs}$ inhibited GJIC based on the results of scrape/loading dye transfer assay for the identification of non-genotoxic tumor-promoting potential. The reduction in expression and plasma membrane localization of $\mathrm{Cx} 43$ was detected following $\mathrm{SiO}_{2} \mathrm{NP}$ treatment. Particularly, $\mathrm{SiO}_{2} \mathrm{NP}$ treatment increased $\mathrm{C} 43$ phosphorylation state, which was significantly attenuated by inhibitors of extracellular signal-regulated kinases 1/2 (ERK1/2) and threonine and tyrosine kinase (MEK), but not by protein kinase $\mathrm{C}$ (PKC) inhibitor. Taken together, in addition to a significant increase in DNA breakage, $\mathrm{SiO}_{2} \mathrm{NP}$ treatment resulted in GJIC dysregulation involved in $\mathrm{Cx} 43$ phosphorylation through the activation of mitogen-activated protein kinase (MAPK) signaling. Overall findings of the genotoxic and non-genotoxic carcinogenic potential of $\mathrm{SiO}_{2} \mathrm{NPs}$ provide useful toxicological information for clinical application at an appropriate dose.
\end{abstract}

Keywords: nanoparticles; amorphous silica; genotoxicity; gap junctional intercellular communication; tumor promoting potential

\section{Introduction}

Nanoparticles are materials measuring less than $100 \mathrm{~nm}$ in at least one dimension. Due to the unique physical and chemical properties of nanomaterials compared with their micro-sized counterparts, nanotechnology is one of the most rapidly growing technologies in various fields including food, agriculture, energy, materials, healthcare, and medicine [1-3]. Nonetheless, nanoparticles are associated 
with major safety concerns following broader human exposure. Since the ultra-small size of nanomaterial facilitates its diffusion across biological barriers [4], smaller particles with a larger surface area are more toxic with a higher absorption rate than the larger ones [5,6]. Indeed, Warheit et al. [7] found that nanoscale $\mathrm{TiO}_{2}$ induces transient inflammatory cells after pulmonary instillation in rats. Kim et al. [8] found that silver nanoparticles trigger oxidative stress in human hepatoma cells. Raghunathan et al. [9] reported chrome nanoparticle-induced genotoxicity by inducing reactive oxygen species. Exposure to zinc oxide nanoparticles led to cytotoxicity, genotoxicity, and inflammatory responses in human nasal mucosa cells [10]. Meanwhile, Magaye et al. [11] reported genotoxicity and carcinogenicity of cobalt, nickel, and copper-based nanoparticles.

Silicon dioxide, also known as silica, exists in three forms: crystalline, amorphous, and fused silica. Among them, there is extensive evidence that crystalline silica is toxic. Excessive exposure to crystalline silica has been known to increase the risk of pulmonary diseases such as silicosis and lung cancer [12]. Fused silica particles are reported to induce interleukin-1 $\beta$ (IL-1 $\beta$ ) release from lipopolysaccharide (LPS)-primed mouse macrophage-like cell line RAW264.7 [13]. As another form of silica, amorphous silica has a wide range of applications including food and cosmetic industries as well as in medicine via targeted drug/DNA delivery, cancer therapy, enzyme immobilization, and in dentistry as an abrasive agent [14-18]. Although amorphous silica has been considered to be a less toxic form, its toxicity is still highly disputed. Ryu et al. [19] did not find any toxicity or change in organs following exposure to amorphous silica nanoparticles ( $\left.\mathrm{SiO}_{2} \mathrm{NPs}\right)$. Uboldi et al. [15] also have shown that $\mathrm{SiO}_{2} \mathrm{NPs}_{\mathrm{did}}$ not induce cytotoxicity, cell transformation, or genotoxicity in mouse fibroblast cells. In contrast, $\mathrm{SiO}_{2} \mathrm{NPs}$ are known to cause cytotoxicity, resulting in oxidative stress and apoptosis of epithelial cells in human skin and lung [16]. Guichard et al. [20] demonstrated cytotoxicity and genotoxicity of $\mathrm{SiO}_{2} \mathrm{NPs}_{\text {in vitro. }}$

Based on the current knowledge on the genotoxic and carcinogenic potential of various nanoparticles [11], the present study was designed to provide conclusive information on the genotoxic potential of $\mathrm{SiO}_{2} \mathrm{NPs}$ using a battery of four standard genotoxicity tests including the Ames test, in vitro chromosome aberration test, in vivo micronucleus test, and additional in vitro comet assay, in compliance with the Good Laboratory Practices for toxicity test guidance issued by the Ministry of Food and Drug Safety [21]. Further, to investigate the non-genotoxic carcinogenic potential of $\mathrm{SiO}_{2} \mathrm{NPs}$, we also conducted gap junctional intercellular communication (GJIC) analysis, a rapid and simple protocol to detect tumor promoters [22-25]. Gap junction consists of two intercellular hemichannels called connexons. A connexon is composed of six connexins that directly link the cytoplasm of neighboring cells and facilitate the passage of ions and signaling molecules, nucleotides, inositol triphosphate, $\mathrm{Ca}^{2+}$, second messengers, and other essential cellular components to maintain homeostasis, cell growth, proliferation, differentiation and other physiological events [26]. Thus, GJIC dysfunction can cause loss of homeostasis, resulting in carcinogenesis [24,25]. Using this approach, we identified the tumor-promoting potential of the $\mathrm{SiO}_{2} \mathrm{NPs}$ and its mechanism associated with abnormal GJIC. Based on the genotoxic and non-genotoxic carcinogenic potential of the $\mathrm{SiO}_{2} \mathrm{NPs}_{\text {, }}$ we provide comprehensive preclinical data for the clinical use (Figure 1).

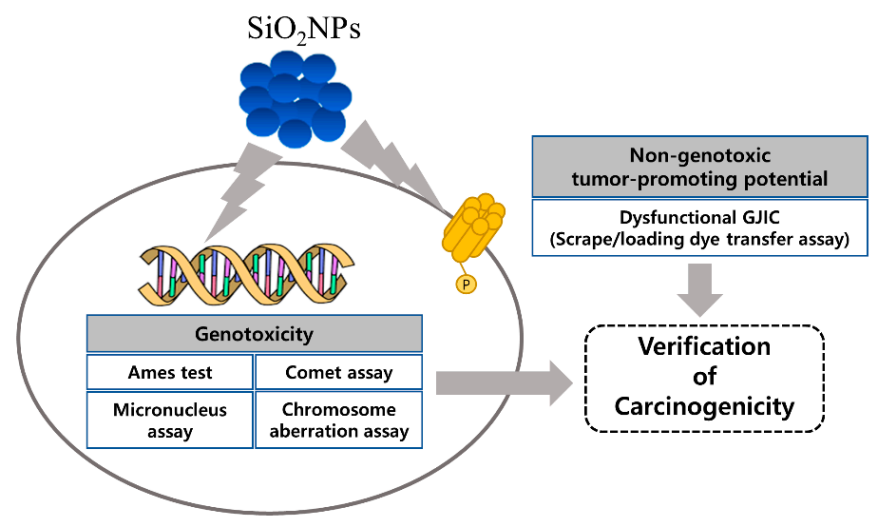

Figure 1. Schematic representation of the experimental design. 


\section{Materials and Methods}

\subsection{Physicochemical Characterization}

Particle size and morphology of $\mathrm{SiO}_{2} \mathrm{NPs}$ (Nanostructured and Amorphous Materials Inc., Houston, TX, USA) were evaluated with a transmission electron microscope (TEM) (JEOL 2010F, JEOL, Tokyo, Japan). Stock suspensions of particles were prepared in $\mathrm{ddH}_{2} \mathrm{O}$ by sonication for $1 \mathrm{~h}$ (pulse on $30 \mathrm{~s}$ /pulse off $30 \mathrm{~s}$ each cycle) in a dark room to prevent the effect of light. This suspension was pipetted onto the formvar/carbon-coated TEM grid. After droplets were left to dry at room temperature, they were photographed. The sizes of 20 particles on the grid were measured and their average value was calculated. Scanning electron microscopy (SEM) was utilized to study the morphology of $\mathrm{SiO}_{2} \mathrm{NPs}$ by using an SU8010 High Resolution Field Emission Scanning Electron Microscope (Hitachi, Ltd., Tokyo, Japan). Elemental composition of $\mathrm{SiO}_{2} \mathrm{NPs}$ was confirmed and quantified using the energy dispersive X-ray detection (EDX) feature of the SEM. The hydrodynamic size and zeta potential of $\mathrm{SiO}_{2} \mathrm{NPs}$ were determined by dynamic light scattering (DLS) with a Zetasizer Nano-ZS instrument (Malvern, Herremberg, Germany). The DLS measurement was performed 30 min after suspension preparation at a concentration of $1 \mathrm{mg} / \mathrm{mL}$.

\subsection{Ames Test}

Bacterial reverse mutation assay (Ames test) was conducted in accordance with the Organization for Economic Cooperation and Development (OECD) guideline 471 [27] using characterized histidine-requiring strains of Salmonella typhimurium (TA98, TA100, TA1535, TA1537; Ministry of Food and Drug Safety, Osong, Korea), and Escherichia coli (WP2uvrA; MOLTOX, Boone, NC, USA) to investigate the potential mutagenicity of $\mathrm{SiO}_{2} \mathrm{NPs}$. These test strains were treated with $\mathrm{SiO}_{2} \mathrm{NPs}$ at doses of 1250,2500 , and $5000 \mu \mathrm{g} / 100 \mu \mathrm{L} /$ plate with or without an exogenous metabolic activation (S9 mix) in the dark at $37{ }^{\circ} \mathrm{C}$ for $48 \mathrm{~h}$. The following compounds were used as positive controls: 2-nitrofluorene, sodium azide, mitomycin C, 9-aminoacridine, and 2-aminoanthracene (Sigma-Aldrich, St. Louis, MO, USA). A $\geq 2$-fold increase and a concentration-dependent increase in the number of revertant colonies relative to the negative control were considered positive for mutagenicity.

\subsection{In Vitro Chromosomal Aberration Study}

Chromosomal aberrations were analyzed using Chinese hamster lung (CHL) fibroblasts, a widely used test system for in vitro genotoxicity studies, according to the OECD guideline 473 [28]. CHL fibroblasts were treated with $\mathrm{SiO}_{2} \mathrm{NPs}(133.38,153.39,176.4 \mu \mathrm{g} / \mathrm{mL})$, mitomycin C $(0.1 \mu \mathrm{g} / \mathrm{mL})$, and cyclophosphamide $(5 \mu \mathrm{g} / \mathrm{mL})$ in the presence or absence of $\mathrm{S} 9 \mathrm{mix}$ for $6 \mathrm{~h}$ or $24 \mathrm{~h}$ in a $5 \% \mathrm{CO}_{2}$ atmosphere at $37^{\circ} \mathrm{C}$. The cells were washed and incubated in complete medium for an additional $18 \mathrm{~h}$. After the addition of colcemid (Gibco, Carlsbad, CA, USA) at a final concentration of $0.2 \mu \mathrm{g} / \mathrm{mL} \mathrm{for} 2 \mathrm{~h}$, the cells were swollen in a hypotonic solution, fixed in 3:1 methanol/glacial acetic acid, and stained with $4 \%$ Giemsa.

\subsection{In Vivo Bone Marrow Micronucleus Test}

An in vivo bone marrow micronucleus test was conducted using male ICR(CrljOri:CD1) mice (Orient Bio, Seongnam, Korea) aged 7 weeks according to the OECD guideline 474 [29]. The animal experiments were reviewed and approved by the Institutional Animal Care and Use Committee of the Biomedical Research Institute at the Seoul National University Hospital (Identification code: 12-0373, Approved date: 1 January 2013. $\mathrm{SiO}_{2} \mathrm{NPs}$ were administered daily via oral gavage for 4 days at doses of 500, 1000, and $2000 \mathrm{mg} / \mathrm{kg}$ of body weight. Mitomycin C was administered intraperitoneally at a dose of $2 \mathrm{mg} / \mathrm{kg}$ of body weight as a positive control. All mice were sacrificed at $24 \mathrm{~h}$ after treatment, and femurs were removed to obtain bone marrow cells. The cells were centrifuged, smeared onto slides, dried, and fixed in methanol. The fixed slides were stained with 5\% Giemsa. A total of 2000 polychromatic erythrocytes (PCEs) were counted to determine the frequency of micronucleated 
polychromatic erythrocytes (MNPCEs). Additionally, the ratio of PCEs to PCEs + normochromatic erythrocytes (NCEs), where the NCEs denote the normochromatic erythrocytes, was calculated by counting a total of 1000 erythrocytes to determine the possibility of bone marrow cytotoxicity [30].

\subsection{In Vitro Comet Assay}

The comet assay was performed with CHL cells to evaluate the DNA damage induced by $\mathrm{SiO}_{2} \mathrm{NPs}$ as described by Singh et al. [31] and Olive et al. [32]. The cells were exposed to $\mathrm{SiO}_{2} \mathrm{NPs}_{\text {at }} 37.5,75$, and $150 \mu \mathrm{g} / \mathrm{mL}$ for 4 or $24 \mathrm{~h}$ in the presence or absence of S9 mix. Ethyl methanesulfonate (EMS) at $500 \mu \mathrm{g} / \mathrm{mL}$ was used as a positive control. The treated cells were collected, mixed with a low melting point agarose $(0.8 \%)$, spread onto pre-coated glass slides, covered with a glass coverslip, and placed at $4{ }^{\circ} \mathrm{C}$. After the coverslip was removed, the slides were placed in a lysis solution $(2.5 \mathrm{M} \mathrm{NaCl}, 100 \mathrm{mM}$ EDTA, $10 \mathrm{mM}$ Tris-HCl, 1\% Triton X-100, 10\% (v/v) DMSO) and unwinding buffer (1 mM EDTA, $300 \mathrm{mM} \mathrm{NaOH}, \mathrm{pH}>13$ ), and subjected to electrophoresis. Next, the slides were neutralized with $0.4 \mathrm{M}$ Tris- $\mathrm{HCl}$ ( $\mathrm{pH} 7.5)$ for $10 \mathrm{~min}$, stained with ethidium bromide $(2 \mu \mathrm{g} / \mathrm{mL})$, and analyzed using fluorescence microscopy. DNA damage was determined by $\%$ tail DNA and Olive tail moment $(\%$ tail DNA $\times$ tail movement length) based on the random scoring of 100 nuclei per slide.

\subsection{Cell Culture and Treatments for GJIC Analysis}

Cytotoxicity was measured using a trypan blue exclusion assay as described by Strober [33] with some modifications. In brief, WB-F344 rat liver epithelial stem-like cells were seeded onto a 24-well plate and grown in D-medium (Gibco) supplemented with 5\% fetal bovine serum (Gibco), $0.5 \%$ penicillin-streptomycin-neomycin antibiotic mixture (Gibco), sodium bicarbonate (Amresco, Solon, OH, USA), sodium pyruvate (Sigma-Aldrich), D-glucose (Sigma-Aldrich), and sodium chloride (Sigma-Aldrich) at $37^{\circ} \mathrm{C}$ in a $5 \% \mathrm{CO}_{2}$ humidified incubator. To determine the concentration that results in $70-80 \%$ viability compared with the negative control, WB-F344 cells were exposed to $\mathrm{SiO}_{2} \mathrm{NPs}$ at different concentrations up to $5000 \mu \mathrm{g} / \mathrm{mL}$ for $24 \mathrm{~h}$. After exposure to a mixture of $0.4 \%$ trypan blue, viability was determined as the percentage of cells with clear cytoplasm (viable cells) versus cells that contained trypan blue in the cytoplasm (dead cells). For the time-course experiments investigating the function of GJIC using scrape loading/dye transfer (SL/DT) assay, WB-F344 cells were treated with $\mathrm{SiO}_{2} \mathrm{NPs}$ at a dose of $5000 \mu \mathrm{g} / \mathrm{mL}$ for 3, 6, 12, and $24 \mathrm{~h}$. In the dose-dependent study, the cells were treated with 200, 1000, and $5000 \mu \mathrm{g} / \mathrm{mL}$ of $\mathrm{SiO}_{2} \mathrm{NPs}$ for $12 \mathrm{~h}$. As a positive control, 12-O-tetradecanocylphorbol-13-acetate (TPA) was added at a dose of $10 \mathrm{ng} / \mathrm{mL}$. To identify the mechanism of $\mathrm{SiO}_{2} \mathrm{NP}$-induced GJIC inhibition, WB-F344 cells were pretreated with $50 \mu \mathrm{M}$ extracellular signal-regulated kinase (ERK) inhibitor PD98059 (Sigma-Aldrich), $10 \mu \mathrm{M}$ mitogen-activated protein kinase kinase (MEK) inhibitor U0126 (Sigma-Aldrich), and $10 \mu \mathrm{M}$ protein kinase C (PKC) inhibitor bisindolylmaleimide I (BIM I) (Calbiochem, San Diego, CA, USA) for $30 \mathrm{~min}$ before exposure to $5000 \mu \mathrm{g} / \mathrm{mL} \mathrm{SiO}_{2} \mathrm{NPs}$ for $12 \mathrm{~h}$.

\subsection{SL/DT Assay for GJIC Analysis}

The SL/DT assay was conducted to measure GJIC using Lucifer yellow dye migration through all connexin channels with the scrape and load technique [34]. After cells were washed 3 times with Dulbecco's phosphate-buffered saline (D-PBS) without $\mathrm{Ca}^{2+}$ and $\mathrm{Mg}^{2+}, 0.05 \%$ Lucifer yellow dye (Sigma-Aldrich) dissolved in D-PBS was added to cells and six scrapes were made with a surgical steel blade. After 9 min of incubation at room temperature in the dark, the Lucifer yellow was discarded. Cells were washed 3 times with D-PBS and fixed with $4 \%$ formaldehyde solution. The GJIC activity was analyzed by monitoring the extent of diffusion of the fluorescent dye Lucifer yellow from the scrape line into adjacent cells through functional gap junctions using an inverted fluorescent microscope (IX61, Olympus, Tokyo, Japan). 


\subsection{Immunofluorescence Staining of C $x 43$}

Immunofluorescence staining was carried out to verify the quantification and localization of Cx43 protein. WB-F344 cells seeded on the 8-well chamber slide were blocked with $3 \%$ bovine serum albumin (BSA) (Amresco) in PBS containing 0.05\% Tween 20 for $1 \mathrm{~h}$ at room temperature. After the supernatant was discarded, cells were incubated overnight with rabbit polyclonal anti-Cx43 antibody (Sigma-Aldrich) at $4{ }^{\circ} \mathrm{C}$. After washing 3 times, the cells were incubated with goat anti-rabbit immunoglobulin G (IgG) secondary antibody (Molecular Probes, Eugene, OR, USA) for $1 \mathrm{~h}$ at room temperature. Cells were washed 3 times with D-PBS and fixed with 4\% paraformaldehyde for 20 min at room temperature. Samples were mounted and photographed with an inverted fluorescent microscope.

\subsection{Western Blot Analysis}

Western blot was used to measure the phosphorylation of Cx43, ERK, MEK, and PKC. Proteins were extracted with radioimmunoprecipitation (RIPA) buffer (Millipore, Bedford, MA, USA) containing $0.1 \%$ protease inhibitor (Sigma-Aldrich) and phosphatase inhibitor (Sigma-Aldrich), and centrifuged at $13,000 \mathrm{rpm}$ for $20 \mathrm{~min}$ at $4{ }^{\circ} \mathrm{C}$. The supernatants were collected, and the protein contents were determined using the bicinchoninic acid (BCA) protein assay kit (Pierce Biotechnology, Rockford, IL, USA), followed by $12 \%$ SDS-PAGE of $20 \mu \mathrm{g}$ proteins and transfer to polyvinylidene difluoride membranes (Bio-Rad, Richmond, CA, USA). The membrane was incubated with anti-Cx43 (Sigma-Aldrich), anti-pERK1/2 (Cell signaling Technology, Beverly, MA, USA), anti-ERK1/2 (Cell signaling Technology), anti-pMEK (Cell signaling Technology), anti-MEK (Cell signaling Technology), anti-PKC (Santa Cruz Biotechnology, Santa Cruz, CA, USA), or anti-pPKC (Biovision Inc., Milpitas, CA, USA) antibodies overnight at $4{ }^{\circ} \mathrm{C}$. Signals were detected with a chemiluminescence kit (GE Healthcare, Buckinghamshire, UK) according to the manufacturer's instructions. The relative band intensity and phosphorylation status were quantified with an image-analysis program using Image J (NIH, Bethesda, MD, USA) or Scion Image (NIH).

\subsection{Statistical Analysis}

The data were expressed as means \pm SD. Statistical analysis was performed using a one-way ANOVA or Student's $t$-test using SPSS software version 24 (SPSS Inc., Chicago, IL, USA). $p$ values $\leq 0.05$ were considered statistically significant.

\section{Results}

\subsection{Characterization of $\mathrm{SiO}_{2} \mathrm{NPS}$}

The characterization of nanoparticles is a basic step in the evaluation of potential toxicity. As a nanoparticle is characterized by less than $100 \mathrm{~nm}$ at least in one dimension, the size and morphology of $\mathrm{SiO}_{2} \mathrm{NPs}$ were verified by TEM. The morphology of the $\mathrm{SiO}_{2} \mathrm{NPs}$ used in this study was spherical with no impurity (Figure 2A).

The measured TEM-size of $\mathrm{SiO}_{2} \mathrm{NPs}$ was $18.54 \pm 5.05 \mathrm{~nm}$ (Table 1). Scanning electron microscopy analysis provided further insight into morphology of $\mathrm{SiO}_{2} \mathrm{NPs}$ and the $\mathrm{SiO}_{2} \mathrm{NPs}$ were spherical in shape (Figure 2B). For the confirmation of elemental analysis, $\mathrm{SiO}_{2} \mathrm{NPs}$ was subjected to the EDX analysis. The results indicated that $\mathrm{SiO}_{2} \mathrm{NPs}$ were composed of the highest purity because no peak belonging to impurity was detected (Figure 2C). Platinum and carbon were detected because $\mathrm{SiO}_{2} \mathrm{NPs}_{\mathrm{S}}$ was coated with platinum before EDX analysis and $\mathrm{SiO}_{2} \mathrm{NPs}$ was pasted on carbon tape during detecting, respectively. DLS can also be used to evaluate the hydrodynamic size and zeta potential [10]. Kaszuba and Connah [35] indicated that the concentration of particles can affect light scattering when measuring hydrodynamic size by DLS. If the concentration of the particle is too high, multiple scattering effect can occur, which leads to reduction in hydrodynamic size. Therefore, in this study, DLS analysis was performed using suspensions of $\mathrm{SiO}_{2} \mathrm{NPs}$ at a concentration of $1 \mathrm{mg} / \mathrm{mL}$, not $50 \mathrm{mg} / \mathrm{mL}$ used as the highest concentration in the Ames test. Our finding showed a hydrodynamic size of $69.35 \mathrm{~nm}$ 
(Figure 2D and Table 1), indicating that $\mathrm{SiO}_{2} \mathrm{NPs}$ may form minimal agglomeration/aggregation and were appropriate for nanotoxicity studies. The zeta potential of $\mathrm{SiO}_{2} \mathrm{NPs}$ in water diluted to $0.1 \mathrm{mg} / \mathrm{mL}$ was $-32.2 \mathrm{mV}$ (Figure 2E and Table 1). The absolute zeta potential of $30 \mathrm{mV}$ or more is stable enough to overcome aggregation caused by the action of Van der Waals forces [36].

(A)
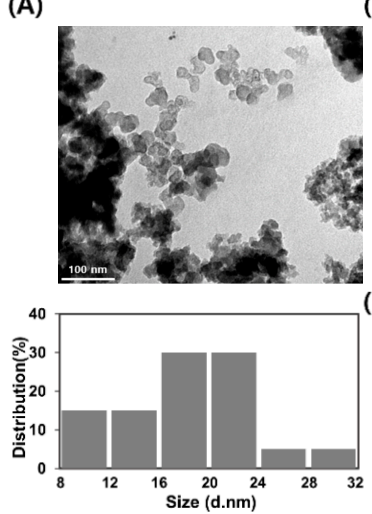

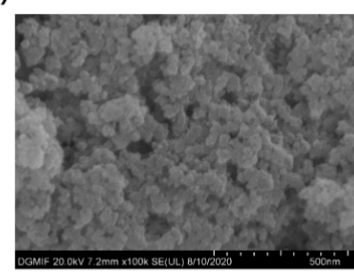

(C)

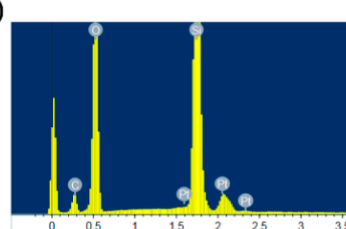

(D)
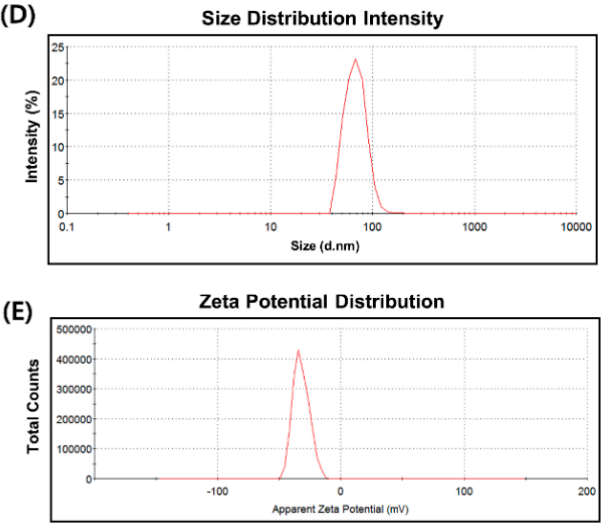

Figure 2. Characterization of amorphous silica nanoparticles $\left(\mathrm{SiO}_{2} \mathrm{NPs}\right)$. (A) Representative TEM image and size distribution histogram of $\mathrm{SiO}_{2} \mathrm{NPs}$. (B) Representative SEM image of the $\mathrm{SiO}_{2} \mathrm{NPs}_{\text {. }}$ (C) energy dispersive X-ray detection (EDX) analysis of $\mathrm{SiO}_{2} \mathrm{NPs}$. (D,E) Representative dynamic light scattering (DLS) measurement of $\mathrm{SiO}_{2} \mathrm{NPs}$ for (D) hydrodynamic size and (E) zeta potential.

Table 1. Physico-chemical characterization of $\mathrm{SiO}_{2} \mathrm{NPs}$.

\begin{tabular}{ccc}
\hline${\text { Particle Diameter }(\mathbf{n m})^{\mathbf{a}}}$ & ${\text { Hydrodynamic Size }(\mathbf{n m})^{\mathbf{b}}}_{\text {Zeta-Potential }(\mathbf{m V})^{\mathbf{c}}}$ \\
\hline $18.54 \pm 5.05$ & $68.78 \pm 2.43$ & $-32.07 \pm 0.32$ \\
\hline
\end{tabular}

a Diameter determined in deionized water by TEM. ${ }^{\text {b }}$ Hydrodynamic size determined in deionized water by DLS.

${ }^{c}$ Zeta-potential determined by DLS. Data are represented as the mean \pm standard deviation of triplicate measurements.

\section{2. $\mathrm{SiO}_{2} \mathrm{NPs}$ Exposure Results in Ames Test}

The results of the Ames test with S. typhimurium TA98, TA100, TA1535, TA1537, and E. coli WP2uvrA, which is used to determine the mutagenicity potential of $\mathrm{SiO}_{2} \mathrm{NPs}$, are presented in Table 2 . As expected, standard mutagens used as positive controls (2-nitrofluorene, sodium azide, mitomycin C, 9-aminoacridine, and 2-aminoanthracene) for the respective strains caused a significant increase in the number of $\mathrm{His}^{+}$revertant colonies in the presence or absence of the $\mathrm{S} 9 \mathrm{mix}$, indicating that the test conditions and the metabolic activation system were adequate. In contrast, no significant increases in the number of revertants were observed in all bacterial strains with or without S9 mix upon treatment with $\mathrm{SiO}_{2} \mathrm{NPs}$ at doses of 1250,2500 , and $5000 \mu \mathrm{g} / 100 \mu \mathrm{L} /$ plate selected based upon preliminary results from cytotoxicity testing (Supplementary Materials Table S1).

Table 2. Results of $S$. typhimurium reversion assay with $\mathrm{SiO}_{2} \mathrm{NPs}$.

\begin{tabular}{|c|c|c|c|c|c|c|c|}
\hline S9 & Substance & $\begin{array}{c}\text { Dose } \\
(\mu \mathrm{g} / 100 \mu \mathrm{L} / \text { plate })\end{array}$ & \multicolumn{5}{|c|}{ His $^{+}$Revertant Colony/Plate } \\
\hline \multirow{6}{*}{-} & Distilled water ${ }^{a}$ & - & $28 \pm 5.1$ & $125 \pm 8.7$ & $22 \pm 2.1$ & $12 \pm 1.7$ & $16 \pm 3.0$ \\
\hline & 2-nitrofluorene ${ }^{b}$ & 10 & $640 \pm 54.1 *$ & - & - & - & - \\
\hline & Sodium azide ${ }^{b}$ & 5 & - & $884 \pm 29.8 *$ & - & - & - \\
\hline & Sodium azide ${ }^{b}$ & 0.5 & - & - & - & $419 \pm 22.1 *$ & - \\
\hline & 9-aminoacridine ${ }^{b}$ & 80 & - & - & - & - & $894 \pm 44.5^{*}$ \\
\hline & $\mathrm{SiO}_{2} \mathrm{NPs}$ & $\begin{array}{l}1250 \\
2500 \\
5000\end{array}$ & $\begin{array}{l}29 \pm 1.7 \\
30 \pm 4.5 \\
24 \pm 4.0\end{array}$ & $\begin{array}{l}130 \pm 2.6 \\
129 \pm 5.0 \\
130 \pm 8.5\end{array}$ & $\begin{array}{c}26 \pm 2.6 \\
25 \pm 0.6 \\
22 \pm 2.5\end{array}$ & $\begin{array}{c}8 \pm 2.5 \\
11 \pm 4.2 \\
9 \pm 1.2\end{array}$ & $\begin{array}{l}17 \pm 1.2 \\
18 \pm 2.6 \\
18 \pm 2.5\end{array}$ \\
\hline
\end{tabular}


Table 2. Cont.

\begin{tabular}{|c|c|c|c|c|c|c|c|}
\hline \multirow{2}{*}{ S9 } & \multirow{2}{*}{ Substance } & \multirow{2}{*}{$\begin{array}{c}\text { Dose } \\
(\mu \mathrm{g} / 100 \mu \mathrm{L} / \text { plate })\end{array}$} & \multicolumn{5}{|c|}{ His $^{+}$Revertant Colony/Plate } \\
\hline & & & TA98 & TA100 & WP2uvrA & TA1535 & TA1537 \\
\hline \multirow{3}{*}{+} & Distilled water ${ }^{a}$ & - & $31 \pm 7.4$ & $117 \pm 6.6$ & $38 \pm 1.5$ & $14 \pm 2.5$ & $20 \pm 2.1$ \\
\hline & 2-aminoanthracene ${ }^{b}$ & $\begin{array}{l}2.0 \\
5.0\end{array}$ & $\begin{array}{c}405 \pm 16.5 * \\
-\end{array}$ & $\begin{array}{c}431 \pm 14.0 * \\
-\end{array}$ & $\begin{array}{c}- \\
397 \pm 19.9 *\end{array}$ & $\begin{array}{c}- \\
411 \pm 8.0 *\end{array}$ & $408 \pm 16.1$ * \\
\hline & $\mathrm{SiO}_{2} \mathrm{NPs}$ & $\begin{array}{l}1250 \\
2500 \\
5000\end{array}$ & $\begin{array}{l}34 \pm 0.6 \\
34 \pm 5.9 \\
30 \pm 7.2\end{array}$ & $\begin{array}{c}113 \pm 3.1 \\
114 \pm 4.0 \\
121 \pm 11.9\end{array}$ & $\begin{array}{l}30 \pm 7.5 \\
35 \pm 1.0 \\
31 \pm 2.3\end{array}$ & $\begin{array}{l}14 \pm 0.6 \\
12 \pm 2.5 \\
14 \pm 3.1\end{array}$ & $\begin{array}{l}18 \pm 1.5 \\
18 \pm 0.6 \\
19 \pm 1.0\end{array}$ \\
\hline
\end{tabular}

${ }^{\mathrm{a}}$ Negative control. ${ }^{\mathrm{b}}$ Positive control. * Significantly different from the negative control group $(p<0.05)$.

\section{3. $\mathrm{SiO}_{2} \mathrm{NPs}$ Exposure Results In Vitro Chromosomal Aberration Assay}

As shown in a preliminary 3-[4,5-dimethylthiazol-2-yl]-2,5 diphenyl tetrazolium bromide (MTT) assay in CHL cells (Table S2), dose-dependent cytotoxicity was observed after $\mathrm{SiO}_{2} \mathrm{NP}$ treatments. Although it is possible that bioavailabilities higher than $100 \%$ in the treatments of low doses of SiO2NPs might be due to magnetic properties and catalytic activity [37], redox properties [38], or lixiviation of nanoparticle ions [39], these were not very high (107.48-114.37\%). Based on the results of the MTT assay, $176.4 \mu \mathrm{g} / \mathrm{mL}$ of $\mathrm{SiO}_{2} \mathrm{NPs}$ with a cell survival rate of $73.21 \%$ was selected as the highest concentration for an in vitro chromosomal aberration assay. The positive controls, $0.1 \mu \mathrm{g} / \mathrm{mL}$ mitomycin C (-S9) and $5 \mu \mathrm{g} / \mathrm{mL}$ cyclophosphamide (+S9), exhibited a significant increase in the incidence of chromosomal aberrations, including breaks, fragments, and exchanges, compared with the negative control group. Under this valid condition, $\mathrm{SiO}_{2} \mathrm{NPs}$ did not increase the incidence of chromosomal aberrations with or without exogenous metabolic activation at doses of 133.38, 153.39, and 176.4 $\mu \mathrm{g} / \mathrm{mL}$ (Table 3).

Table 3. Results of chromosomal aberration induced by $\mathrm{SiO}_{2} \mathrm{NPs}$.

\begin{tabular}{|c|c|c|c|c|c|}
\hline \multirow{3}{*}{ Substance } & \multirow{3}{*}{ Dose $(\mu \mathrm{g} / \mathrm{mL})$} & \multirow{3}{*}{ Number of Cells Scored } & \multicolumn{3}{|c|}{ No. of Cells with Aberrations } \\
\hline & & & \multicolumn{2}{|c|}{$-\mathrm{S9}$} & \multirow{2}{*}{$\begin{array}{c}+\mathrm{S} 9 \\
6 \mathrm{~h}\end{array}$} \\
\hline & & & $6 \mathrm{~h}$ & $24 \mathrm{~h}$ & \\
\hline MEM $^{\mathrm{a}}$ & - & 200 & $0.5 \pm 0.71$ & $1.0 \pm 0.00$ & 0 \\
\hline Mitomycin $C^{b}$ & 0.1 & 200 & $26.0 \pm 2.83 *$ & $36.5 \pm 2.12 *$ & - \\
\hline Cyclophosphamide ${ }^{b}$ & 5 & 200 & - & - & $48.5 \pm 0.71$ * \\
\hline Distilled water & - & 200 & 0 & $0.5 \pm 0.71$ & $0.5 \pm 0.71$ \\
\hline \multirow{3}{*}{$\mathrm{SiO}_{2} \mathrm{NPs}$} & 133.38 & 200 & 0 & $0.5 \pm 0.71$ & $0.5 \pm 0.71$ \\
\hline & 153.39 & 200 & $1.0 \pm 1.41$ & $0.5 \pm 0.71$ & 0 \\
\hline & 176.40 & 200 & 0 & 0 & 0 \\
\hline
\end{tabular}

${ }^{a}$ Minimum essential medium (negative control). ${ }^{\mathrm{b}}$ Positive control. ${ }^{*}$ Significantly different from the negative control group $(p<0.05)$.

\section{4. $\mathrm{SiO}_{2} \mathrm{NPs}$ Exposure Results In Vivo Bone Marrow Micronucleus Assay}

In vivo micronucleus assay was conducted to detect the structural (clastogenic) and numerical (aneugenic) chromosome changes following $\mathrm{SiO}_{2} \mathrm{NP}$ treatments. Although the nanoparticles can be introduced into the biological systems through different routes (oral, inhalation, intravenous, etc.), the oral route was chosen as the most likely route of exposure to $\mathrm{SiO}_{2} \mathrm{NPs}$ in this in vivo genotoxicity assay since $\mathrm{SiO}_{2} \mathrm{NPs}$ have been recently reported as an oral drug delivery system [18]. Throughout the study period, no mortality, clinical signs, or abnormalities in body weight (Table S3) were observed following exposure to $\mathrm{SiO}_{2} \mathrm{NPs}$ up to $2000 \mathrm{mg} / \mathrm{kg}$ based on the maximum limit dose recommended in OECD. The mean ratios of the cytotoxicity index PCEs/(PCEs + NCEs) were above $39.8 \%$ in all the tested groups including negative and positive controls (Table 4), indicating a lack of cytotoxicity 
associated with $\mathrm{SiO}_{2} \mathrm{NP}$ treatment under the current test condition [30]. While a statistically significant increase in the number of MNPCEs was detected in the group treated with mitomycin $C$ relative to the negative control value, $\mathrm{SiO}_{2} \mathrm{NP}$ treatments of 500,1000, or $2000 \mathrm{mg} / \mathrm{kg}$ caused no significant increase in MNPCE numbers in mice.

Table 4. Micronucleated polychromatic erythrocytes in mice bone marrow following treatment with $\mathrm{SiO}_{2} \mathrm{NPs}$.

\begin{tabular}{ccccc}
\hline Substance & Dose $^{(\mathbf{m g} / \mathbf{k g} \text { BW) }}$ & Number of Mice & MNPCE $^{\mathbf{c}}$ & PCE/(PCE + NCE) $^{\mathbf{d}}$ \\
\hline Distilled water $^{\mathrm{a}}$ & - & 5 & $2.0 \pm 1.00$ & $49.4 \pm 4.40$ \\
\hline \multirow{2}{*}{$\mathrm{SiO}_{2} \mathrm{NPs}$} & 500 & 5 & $2.0 \pm 1.22$ & $42.9 \pm 10.99$ \\
\cline { 2 - 5 } & 1000 & 5 & $5.4 \pm 2.19$ & $46.2 \pm 4.25$ \\
\hline Mitomycin C $^{\mathrm{b}}$ & 2000 & 5 & $3.8 \pm 0.84$ & $45.7 \pm 4.53$ \\
\hline
\end{tabular}

${ }^{a}$ Negative control. ${ }^{b}$ Positive control. ${ }^{c}$ Polychromatic erythrocyte with micronuclei was calculated from 2000 polychromatic erythrocytes. $d$ The ratio of polychromatic erythrocytes to all erythrocytes (polychromatic + normochromatic) (\%). * Significantly different from the negative control group $(p<0.05)$. ${ }^{* *}$ Significantly different from the negative control group $(p<0.01)$. MNPCE: micronucleated polychromatic erythrocytes, PCE: polychromatic erythrocytes, NCE: normochromatic erythrocytes

\section{5. $\mathrm{SiO}_{2} \mathrm{NPs}$ Exposure Results In Vitro Comet Assay}

Direct measurement of DNA damage was conducted using the comet assay to analyze tail parameters in CHL cells treated with $\mathrm{SiO}_{2} \mathrm{NPs}$ at different concentrations. The comet parameters of tail length and tail moment representing DNA migration during electrophoresis have been developed by Singh et al. [31] and Olive et al. [32] to classify undamaged (no migration) or damaged (migrated DNA) cells. The cells treated with EMS as the positive control showed a strongly positive response in the comet assay, indicating significant increases in DNA damage. Based on the results of the MTT assay in CHL cells (Table S2), the highest concentration of $\mathrm{SiO}_{2} \mathrm{NPs}$ selected for in vitro comet assay

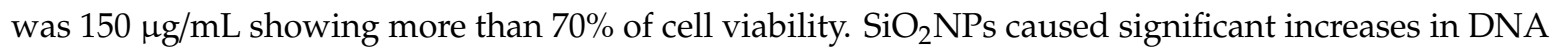
in the tail and Olive tail moment at doses of 37.5, 75, and $150 \mu \mathrm{g} / \mathrm{mL}$ for 4 or $24 \mathrm{~h}$ in the absence of metabolic activation. With S9, the tail and Olive tail moment were significantly increased for $150 \mu \mathrm{g} / \mathrm{mL}$ $\mathrm{SiO}_{2} \mathrm{NP}$ treatment for $4 \mathrm{~h}$ (Figure 3 and Table 5).
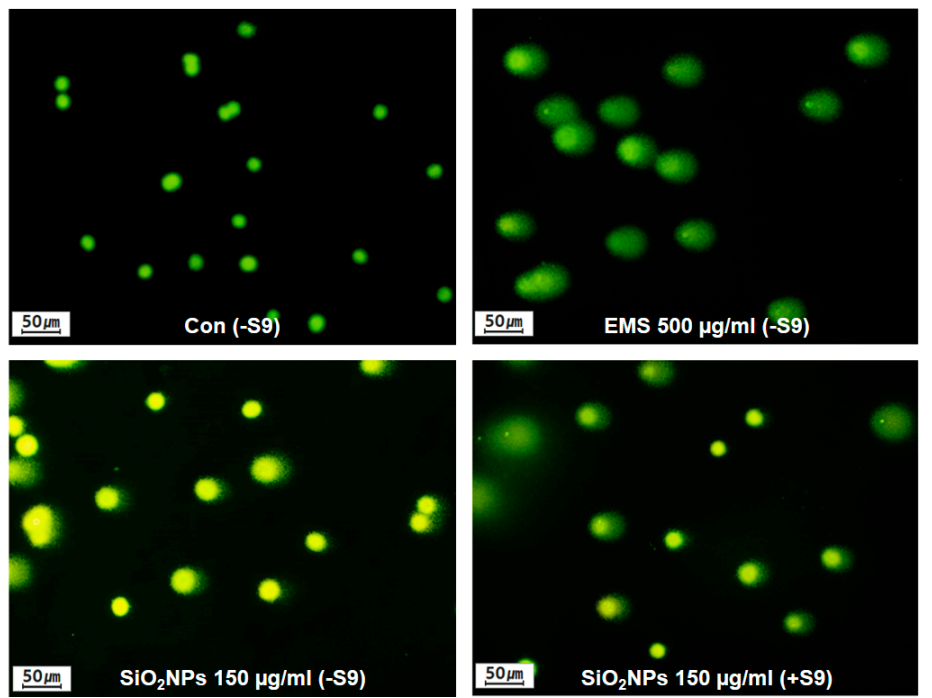

Figure 3. Effects of $\mathrm{SiO}_{2} \mathrm{NPs}$ on DNA damage in CHL cells. Representative in vitro comet assay after the treatment with $150 \mu \mathrm{g} / \mathrm{mL} \mathrm{SiO}_{2} \mathrm{NPs}$ or $500 \mu \mathrm{g} / \mathrm{mL}$ ethyl methanesulfonate (EMS) for $24 \mathrm{~h}$ in the absence of $\mathrm{S} 9 \mathrm{mix}$ and $150 \mu \mathrm{g} / \mathrm{mL} \mathrm{SiO}_{2} \mathrm{NPs}$ for $4 \mathrm{~h}$ in the presence of $\mathrm{S} 9 \mathrm{mix}$. 
Table 5. Results of in vitro comet assay with $\mathrm{SiO}_{2} \mathrm{NPs}$.

\begin{tabular}{|c|c|c|c|c|c|c|}
\hline Substance & Dose $(\mu \mathrm{g} / \mathrm{mL})$ & S-9 Mix & Time (h) & \% Tail DNA & $\begin{array}{l}\text { Olive Tail } \\
\text { Moment }\end{array}$ & $\begin{array}{c}\text { Relative Cell } \\
\text { Count }(\%)\end{array}$ \\
\hline Distilled water ${ }^{a}$ & - & \multirow{5}{*}{-} & 4 & $5.66 \pm 3.66$ & $0.46 \pm 0.31$ & 100 \\
\hline \multirow{3}{*}{$\mathrm{SiO}_{2} \mathrm{NPs}$} & 37.5 & & 4 & $12.16 \pm 6.02 * *$ & $1.29 \pm 1.05^{* *}$ & 98 \\
\hline & 75.0 & & 4 & $13.94 \pm 6.66^{* *}$ & $1.40 \pm 1.13$ ** & 83 \\
\hline & 150.0 & & 4 & $13.11 \pm 6.12 * *$ & $1.19 \pm 1.09 * *$ & 78 \\
\hline EMS $^{b}$ & 500 & & 4 & $25.18 \pm 12.13^{* *}$ & $2.86 \pm 2.34 * *$ & 73 \\
\hline Distilled water ${ }^{a}$ & - & \multirow{5}{*}{ - } & 24 & $5.74 \pm 3.32$ & $0.48 \pm 0.45$ & 100 \\
\hline \multirow{3}{*}{$\mathrm{SiO}_{2} \mathrm{NPs}$} & 37.5 & & 24 & $11.65 \pm 6.39^{* *}$ & $1.11 \pm 1.02$ & 95 \\
\hline & 75.0 & & 24 & $12.17 \pm 6.64 * *$ & $1.07 \pm 1.01$ & 86 \\
\hline & 150.0 & & 24 & $20.51 \pm 10.47^{* *}$ & $2.50 \pm 1.98^{* *}$ & 77 \\
\hline EMS $^{b}$ & 500 & & 24 & $39.44 \pm 14.26^{* *}$ & $8.29 \pm 6.25^{* *}$ & 67 \\
\hline Distilled water ${ }^{a}$ & - & \multirow{5}{*}{+} & 4 & $5.20 \pm 3.20$ & $0.43 \pm 0.32$ & 100 \\
\hline \multirow{3}{*}{$\mathrm{SiO}_{2} \mathrm{NPs}$} & 37.5 & & 4 & $6.13 \pm 3.34$ & $0.47 \pm 0.38$ & 94 \\
\hline & 75.0 & & 4 & $7.47 \pm 3.8$ & $0.62 \pm 0.53$ & 85 \\
\hline & 150.0 & & 4 & $10.10 \pm 5.32 * *$ & $1.00 \pm 0.84^{*}$ & 79 \\
\hline $\mathrm{EMS}^{\mathrm{b}}$ & 500 & & 4 & $24.59 \pm 11.21 * *$ & $3.12 \pm 2.34 * *$ & 76 \\
\hline
\end{tabular}

${ }^{a}$ Negative control. ${ }^{b}$ Positive control. ${ }^{*}$ Significantly different from the negative control group $(p<0.05)$.

** Significantly different from the negative control group $(p<0.01)$.

\section{6. $\mathrm{SiO}_{2} \mathrm{NPs}$ Exposure Results in GIIC Analysis}

As WB-F344 rat liver epithelial cells are stem-like cells and inherently express abundant Cx43 unlike other cell lines [22,40], this cell line was selected for GJIC analysis in the present study. Cell viabilities were measured using a trypan blue exclusion assay following the treatment of $\mathrm{SiO}_{2} \mathrm{NPs}$ in the range of $9.8-5000 \mu \mathrm{g} / \mathrm{mL}$. Since the mean viability of $\mathrm{SiO}_{2} \mathrm{NPs}$ at a concentration of $5000 \mu \mathrm{g} / \mathrm{mL}$

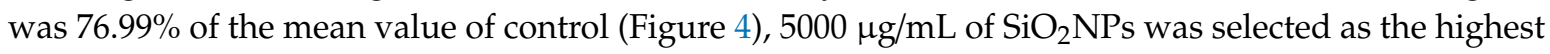
concentration for the subsequent GJIC experiments.

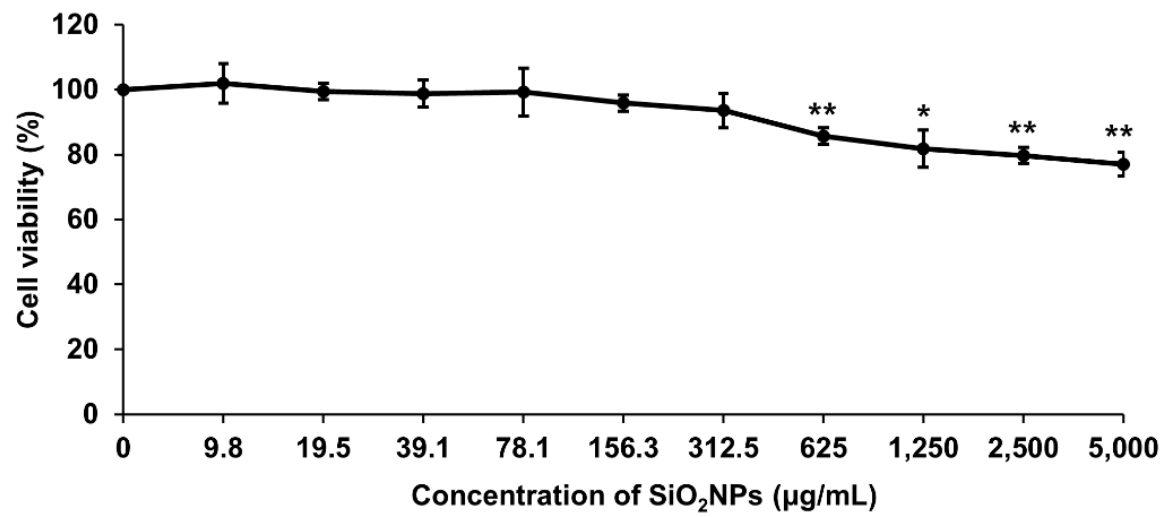

Figure 4. Effects of $\mathrm{SiO}_{2} \mathrm{NPs}$ on cell viability in WB-F344 cells. Data expressed as means $\pm \mathrm{SD}\left({ }^{*} p<0.05\right.$ and $\left.{ }^{* *} p<0.01\right)$.

In a time-course study using the SL/DT method, a simple functional assay for the assessment of GJIC [34], $5000 \mu \mathrm{g} / \mathrm{mL}$ of $\mathrm{SiO}_{2} \mathrm{NPs}$ inhibited GJIC the most (by $37.75 \%$ ) at $12 \mathrm{~h}$ compared with other time points, indicating that the optimal time point was $12 \mathrm{~h}$ for the dose-response study of GJIC (Figure 5A). Additionally, we observed a dose-dependent suppression of dye transfer through functional gap junctions following the $\mathrm{SiO}_{2} \mathrm{NP}$ treatments at 200 (3.17\%), 1000 (23.35\%), and $5000 \mu \mathrm{g} / \mathrm{mL}(38.57 \%)$ for $12 \mathrm{~h}$ (Figure 5B). 
Immunofluorescence staining was performed to determine the expression and localization of Cx43 protein, one of the major gap junction proteins among connexin isotypes [41]. As a result, the expression of $\mathrm{Cx} 43$ decreased in a dose-dependent manner after treatment with $\mathrm{SiO}_{2} \mathrm{NP}_{\text {for }} 12 \mathrm{~h}$ (Figure 5C). Especially, $\mathrm{SiO}_{2} \mathrm{NP}$ treatment caused reductions in $\mathrm{Cx} 43$ localization at regions of cell-cell contact. Since Cx43 phosphorylation is important to evaluate functional gap junctions [41], we further conducted Western blot analysis of Cx43 to elucidate the mechanism of GJIC inhibition by $\mathrm{SiO}_{2} \mathrm{NPs}_{\text {. }}$ Among the three major bands (P0, P1, and P2) on the membrane at 39-44 kDa with the Cx43 antibody, the mobility shifts ranging from band P0 to P1 or P2 indicate the hyperphosphorylation of Cx43 [42]. In the present study, Cx43 was detected on the only P0 and P1 bands in untreated control cells whereas $\mathrm{SiO}_{2} \mathrm{NP}$ treatments dose-dependently increased the phosphorylation of $\mathrm{Cx} 43$ (Figure 6A).

(A)
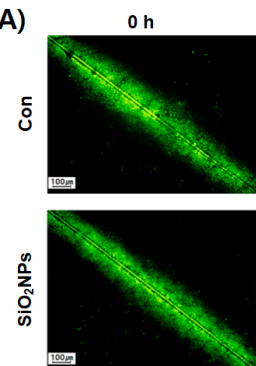

(B)
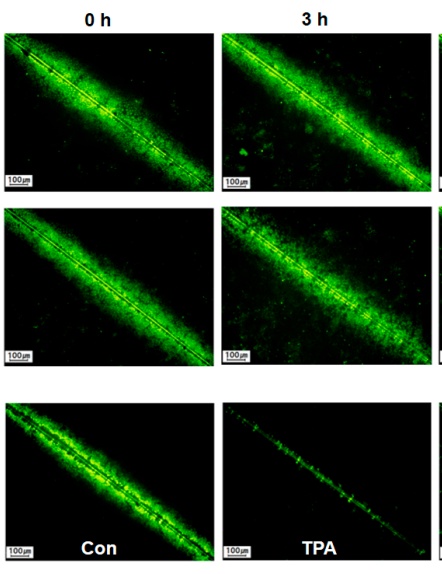

(C)
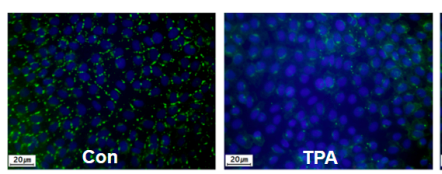
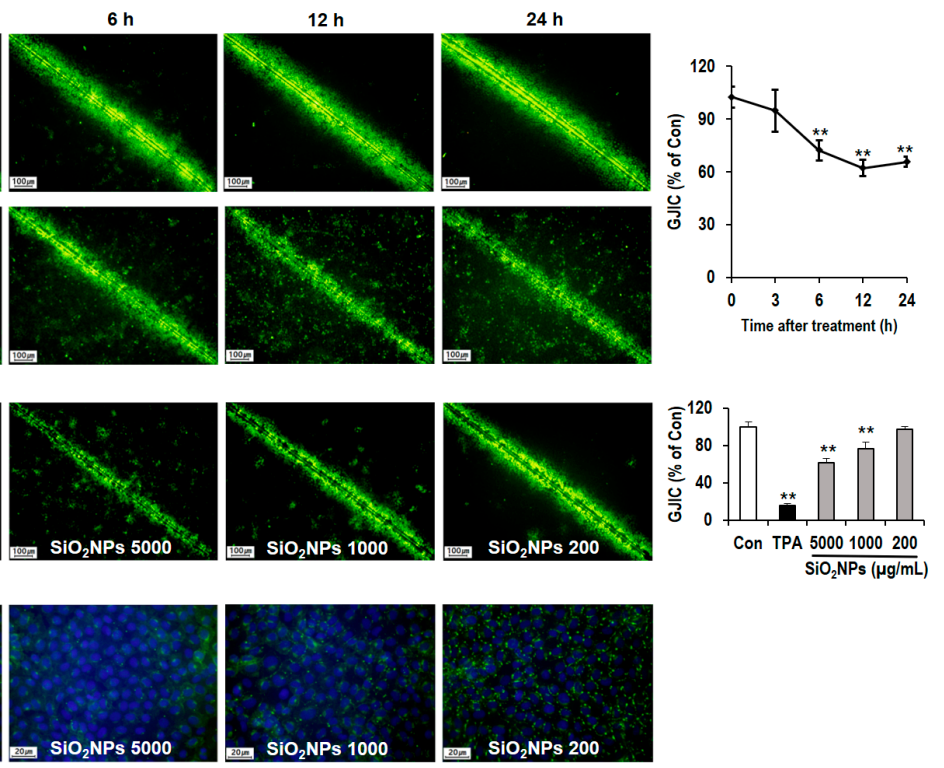

Figure 5. Effects of $\mathrm{SiO}_{2} \mathrm{NPs}$ on gap junctional intercellular communication (GJIC) and Cx43 protein in WB-F344 cells. (A) Representative scrape loading/dye transfer (SL/DT) assay for time-course study on GJIC and quantitative analysis after the treatment with $5000 \mu \mathrm{g} / \mathrm{mL} \mathrm{SiO}_{2} \mathrm{NPs}_{\text {. }}$ (B) Representative SL/DT assay for dose-response study on GJIC and quantitative analysis after the treatment with $\mathrm{SiO}_{2} \mathrm{NPs}_{\text {for }}$ $12 \mathrm{~h}$ at doses of 200, 1000, and $5000 \mu \mathrm{g} / \mathrm{mL}$. Then, $10 \mathrm{ng} / \mathrm{mL}$ 12-O-tetradecanocylphorbol-13-acetate (TPA) was treated as a positive control. (C) Effects of $\mathrm{SiO}_{2} \mathrm{NPs}$ on the distribution of $\mathrm{Cx} 43$. Distribution of Cx43 levels (green) was detected by immunofluorescence staining after the treatment with $\mathrm{SiO}_{2} \mathrm{NPs}$ for $12 \mathrm{~h}$ at doses of 200, 1000, and $5000 \mu \mathrm{g} / \mathrm{mL}$. Then, $10 \mathrm{ng} / \mathrm{mL}$ TPA was treated as a positive control. Nuclei were stained with 4',6-Diamidino-2-phenylindole dihydrochloride (DAPI )(blue). Bar represents $1.0 \mathrm{~mm}$. Data expressed as means $\pm \mathrm{SD}\left({ }^{*} p<0.05\right.$ and $\left.{ }^{* *} p<0.01\right)$.

\subsection{Mechanism of GJIC Inhibition by $\mathrm{SiO}_{2} \mathrm{NPS}$}

Since the activation of the MAPK pathway is closely associated with GJIC regulation [41,43], we analyzed the phosphorylation state of ERK1/2, MEK, and PKC to identify protein kinases related to $\mathrm{Cx} 43$ phosphorylation. In this study, $\mathrm{SiO}_{2} \mathrm{NPs}$ dose-dependently activated the phosphorylation of ERK1/2 and MEK kinases, but not PKC (Figure 6A). We further confirmed the effects of ERK1/2 and MEK kinases on GJIC using the respective inhibitors. In SL/DT assay, pretreatment with ERK1/2 inhibitor (PD98059) and MEK inhibitor (U0126) significantly restored $\mathrm{SiO}_{2} \mathrm{NP}(5000 \mu \mathrm{g} / \mathrm{mL})$-induced inhibition of dye transfer (Figure 6B). Further, the $\mathrm{SiO}_{2} \mathrm{NP}$-induced alterations of expression and plasma membrane localization of Cx43 were significantly blocked, at least partially, by pretreatment with PD98059 and U0126 in immunofluorescence staining whereas PKC inhibitor BIM I did not affect these $\mathrm{SiO}_{2} \mathrm{NP}$-mediated $\mathrm{Cx} 43$ alterations (Figure $6 \mathrm{C}$ ). $\mathrm{SiO}_{2} \mathrm{NP}$-induced phosphorylation of $\mathrm{Cx} 43$ was also 
significantly attenuated by PD98059 and U0126 pretreatment before $\mathrm{SiO}_{2} \mathrm{NPs}$. However, no attenuation of the Cx43 phosphorylation was detected by BIM I pretreatment (Figure 6D).

(A)

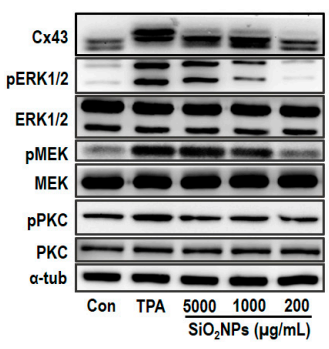

(C)

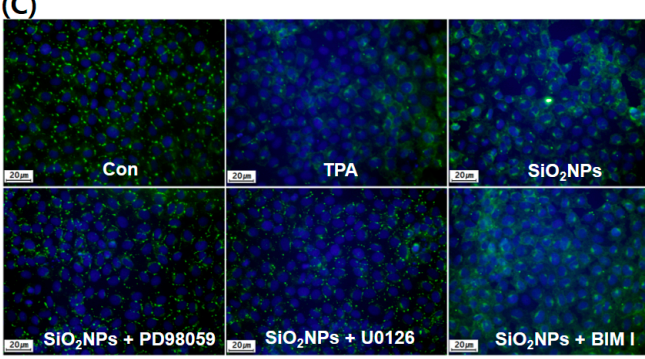

(B)

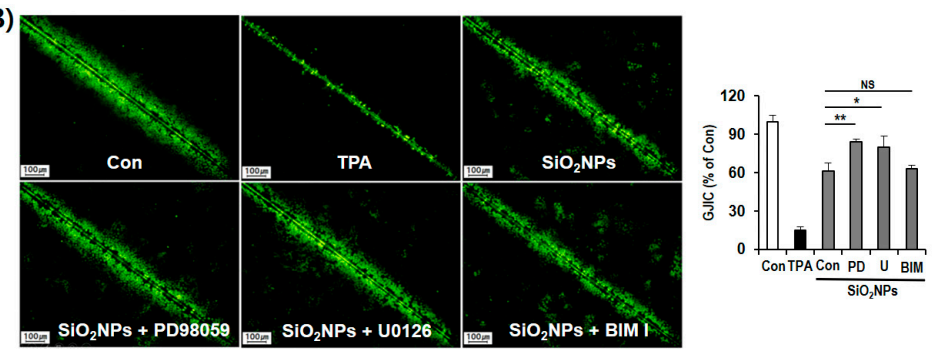

(D)

(E)

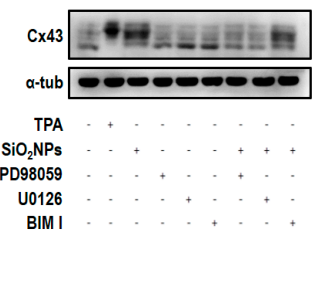

Figure 6. Effects of $\mathrm{SiO}_{2} \mathrm{NPs}$ on phosphorylation $\mathrm{Cx} 43$ in WB-F344 cells. (A) Effects of $\mathrm{SiO}_{2} \mathrm{NPs}$ on Cx43 phosphorylation and MAPK pathway activation in WB-F344 cells. Representative Western blot assay after the treatments with 200,1000, or $5000 \mu \mathrm{g} / \mathrm{mL} \mathrm{SiO}_{2} \mathrm{NPs}$ and $10 \mathrm{ng} / \mathrm{mL}$ TPA for $12 \mathrm{~h}$. (B-D) Effects of MAPKs pathway inhibitors on $\mathrm{SiO}_{2} \mathrm{NP}$-induced GJIC inhibition in WB-F344 cells. The cells were pretreated with $50 \mu \mathrm{M}$ ERK inhibitor PD98059, $10 \mu \mathrm{M}$ MEK inhibitor U0126, and $10 \mu \mathrm{M}$ PKC inhibitor BIM I for $30 \mathrm{~min}$ before the treatment with $5000 \mu \mathrm{g} / \mathrm{mL} \mathrm{SiO}_{2} \mathrm{NPs}_{\text {for }} 12 \mathrm{~h}$. In total, $10 \mathrm{ng} / \mathrm{mL} \mathrm{TPA}$ was treated as a positive control. (B) Representative images for SL/DT assay. NS, not significant. (C) Representative images for immunofluorescence staining. (D) Representative images for Western blot assay. (E) Schematic representation of the inhibition of GJIC by the $\mathrm{SiO}_{2} \mathrm{NPs}$. Data expressed as means $\pm \mathrm{SD}\left({ }^{*} p<0.05\right.$ and $\left.{ }^{* *} p<0.01\right)$. Bar represents $1.0 \mathrm{~mm}$.

\section{Discussion}

The growth of nanotechnology in many fields has raised the risk of unexpected adverse effects associated with nanoparticle exposures. Especially, amorphous silicas have generated substantial interest in nanomedicine $[14,15,17,18,44]$, but some amorphous samples were found to induce cellular damage [45] and proinflammatory responses [46]. Size-dependent pulmonary injury and neutrophilic infiltration were observed in mice that received silica particles via oropharyngeal aspiration [47]. The DNA-damaging potential of amorphous silica was also shown to be size-dependent [48]. Despite these growing safety concerns of $\mathrm{SiO}_{2} \mathrm{NPs}$, its toxicity remains inconclusive due to the lack of comprehensive analysis according to a standardized protocol compared with crystalline silica. In particular, the nanoparticles can be accumulated in the organs by taking a long period to clear, and they may lead to genotoxicity and carcinogenicity as persistent bioaccumulative toxic substances. In fact, Guo et al. [49] reported that the chronic exposure to amorphous $\mathrm{SiO}_{2} \mathrm{NPs}_{\text {saused }}$ malignant transformation of human lung epithelial cell via aberrant p53 signaling. In addition, Xie et al. [50] investigated the tumorigenic mechanisms of $\mathrm{SiO}_{2} \mathrm{NPs}$ associated with oxidative stress and oxidative phosphorylation. Therefore, this study aimed to elucidate the genotoxic and non-genotoxic tumor-promoting effects of $\mathrm{SiO}_{2} \mathrm{NPs}$ along with the possible mechanisms.

We first tested the clastogenic and mutagenic potentials of $\mathrm{SiO}_{2} \mathrm{NPs}$ based on three regulatory genotoxicity studies (a bacterial reverse mutation test, an in vitro chromosome aberration assay, and an in vivo micronucleus assay) according to the OECD test guidelines [27-29] under the principles of Good Laboratory Practices [21]. First, no significant $\mathrm{SiO}_{2} \mathrm{NP}$-related increases in revertant colonies 
were observed in the Ames test used to detect mutagenic effects including base-pair substitutions, frameshift mutations, or oxidative and cross-linking mutations [51-54]. Second, we evaluated the clastogenic activity of $\mathrm{SiO}_{2} \mathrm{NPs}$ with an in vitro mammalian chromosomal aberration test to identify chromosomal breaks, fragments, and exchanges in cultured mammalian cells [55] and in vivo bone marrow micronucleus assay as an indirect indicator of quantitative chromosomal disorders [56], and found that that the $\mathrm{SiO}_{2} \mathrm{NPs}$ did not induce any significant changes regardless of metabolic activation. Even though the aforementioned three genotoxicity tests are the most commonly used screening methods approved by the OECD, some can be inappropriate for nanoparticles. For example, the Ames test has been predominantly negative for various kinds of nanoparticles due to limited or no diffusion through the bacterial wall [57-60]. Therefore, we additionally conducted the in vitro comet assay to quantify DNA damage expressed as \% tail DNA and Olive tail moment, which has higher sensitivity for detecting low levels of DNA damage identifying at the single-cell level [32]. Noteworthy, the $\mathrm{SiO}_{2} \mathrm{NP}$-induced DNA breakage was detected in this study although it was negative in an Ames test, a chromosome aberration assay, and a micronucleus assay. This result can support previous reports on in vitro comet assay involving mammalian cell lines, which has been known to be more sensitive for the genotoxicity of nanoparticles in comparison with other genotoxicity tests $[32,57,59]$ although it is necessary to have a comprehensive evaluation using a battery of different short-term genotoxicity tests together with interpretation criteria to avoid interference and possible false-negative results.

Dysfunctional GJIC has been associated with several diseases such as neuropathy [61], hereditary deafness [62], cataract [63], skin disease [64], and heart disease [65]. Additionally, it is significantly linked to carcinogenesis because it disrupts homeostasis, which modulates cell proliferation and growth in multicellular organisms [66]. Similarly, most tumor cells exhibit dysfunctional GJIC [24] and numerous studies reported that oncogene transfection and treatment with tumor promoters, such as TPA, decreased the GJIC [22,23]. In addition to the genotoxic carcinogen, there are non-genotoxic carcinogens, which produce cancer through secondary mechanisms unrelated to direct gene damage, such as hormonal effects, cytotoxicity, or epigenetic changes [67]. In the present study, to identify the non-genotoxic tumor-promoting potential of $\mathrm{SiO}_{2} \mathrm{NPs}$, we performed the SL/DT assay, which is the most frequently used assay for the assessment of GJIC [34] and found that $\mathrm{SiO}_{2} \mathrm{NPs}$ inhibited dye transfer at doses selected by cell viability assay. Consistently, immunofluorescence staining indicated the dose-dependent reduction in the expression and plasma membrane localization of $\mathrm{Cx} 43$ following $\mathrm{SiO}_{2} \mathrm{NPs}$ treatments, supporting our results from SL/DT assay since $\mathrm{Cx} 43$ internalization is linked to GJIC dysregulation via protein degradation [42].

We investigated the mechanisms underlying the altered expression of $\mathrm{C} \times 43$ by Western blot. First, the phosphorylation of Cx43 in the plasma membrane can lead to inhibition of GJIC through changes in the assembly, stability, and functionality of gap junctions [41]. Second, the low transcriptional output can also be linked to a decreased level of the main gap junction proteins such as Cx43 [68]. Numerous studies have shown that the phosphorylation state of connexin is affected by several exogenous chemicals such as $18 \alpha$-glycyrrhetinic acid, TPA, dieldrin, and heptachlor epoxide [22,41]. In the present study, $\mathrm{SiO}_{2} \mathrm{NPs}$ dose-dependently inhibited GJIC along with the phosphorylation of $\mathrm{Cx} 43$. To investigate the mechanism of $\mathrm{SiO}_{2} \mathrm{NP}$-induced $\mathrm{C} \times 43$ phosphorylation involved in GJIC inhibition, we identified the kinases, which were phosphorylated in the cells treated with $\mathrm{SiO}_{2} \mathrm{NPs}$. Activation of the MEK/ERK/MAP kinase signal transduction pathway has been known to regulate cellular proliferation, survival, and differentiation [69]. Increased levels of MEK and ERK phosphorylation have been reported in response to treatment with well-known carcinogens such as TPA and dichloro-diphenyl-trichloroethane (DDT) [70,71]. Besides, PKC is known to activate MAPK signaling pathway via activation of MEK [72]. In this study, the inhibition of GJIC was found to be mediated by the phosphorylation of $\mathrm{C} \times 3$ through activation of the MAPK pathway. Moreover, the inhibitory activity of $\mathrm{SiO}_{2} \mathrm{NPs}$ on GJIC was restored by ERK inhibitor and MEK inhibitor, but not by PKC inhibitor, indicating a positive relationship between $\mathrm{SiO}_{2} \mathrm{NP}$-induced GJIC suppression and 
MAPK pathway. These led us to the novel discovery on the non-genotoxic carcinogenic potential of $\mathrm{SiO}_{2} \mathrm{NPs}$ and its mechanism involved in abnormal GJIC function.

Many studies have investigated the influence of physicochemical properties of silica nanoparticles such as size, surface charge, geometry, and porosity on their toxicity. Ariano et al. [73] reported that smaller sized silica nanoparticles had a greater ability to induce toxicity and oxidative stress (size ranges from $20 \mathrm{~nm}$ to $500 \mathrm{~nm}$ ) in human hepatoma HepG2 cells. In addition, Yu et al. [74] demonstrated that the porosity and surface charge of silica nanoparticles were found to be important features to control the plasma membrane damage and cytotoxicity in macrophages. In this study, our findings suggest that the in vitro comet assay and GJIC evaluation are appropriate methods for screening of the genotoxic and non-genotoxic carcinogenic potentials of various nanoparticles including $\mathrm{SiO}_{2} \mathrm{NPs}$. Nonetheless, conclusions regarding the correlation of the physicochemical properties of the $\mathrm{SiO}_{2} \mathrm{NPs}$ and its side effects based on the results of comet assay and GJIC analysis would require further verification.

\section{Conclusions}

In the present study, we have herein revealed that the $\mathrm{SiO}_{2} \mathrm{NPs}$ induced dose-dependent DNA damage in the comet assay in mammalian cell lines despite negative responses of $\mathrm{SiO}_{2} \mathrm{NPs}$ detected in the Ames test, chromosomal aberration assays, or micronucleus assays. Further, $\mathrm{SiO}_{2} \mathrm{NP}$-induced Cx43 phosphorylation and subsequent abnormal GJIC occurred in carcinogenesis through activation of the MAPK pathway (Figure 6E). Taken together, this study provides useful information about the potential risk of human exposure to $\mathrm{SiO}_{2} \mathrm{NPs}$ at different concentrations based on the results of comet assay and GJIC analysis.

Supplementary Materials: The following are available online at http://www.mdpi.com/1999-4923/12/9/826/s1, Table S1. Results of cytotoxicity test treated with $\mathrm{SiO}_{2} \mathrm{NPs}$, Table S2. Results of MTT assay in CHL cells treated with $\mathrm{SiO}_{2} \mathrm{NPs}$, Table S3. Effects of $\mathrm{SiO}_{2} \mathrm{NPs}$ on the body weight changes in micronucleus assay.

Author Contributions: Conceptualization, B.-C.K. and J.-W.Y.; methodology, G.-H.L., Y.-S.K., and E.K.; formal analysis, B.-C.K., G.-H.L. and J.-W.Y.; writing-original draft preparation, B.-C.K., G.-H.L. and J.-W.Y.; writing-review and editing, B.-C.K. and J.-W.Y.; supervision, B.-C.K. and J.-W.Y.; project administration, B.-C.K.; funding acquisition, B.-C.K. All authors have read and agreed to the published version of the manuscript.

Funding: This work was supported by the Basic Science Research Program through the National Research Foundation of Korea (NRF) funded by the Ministry of Education (2012R1A1A2009437).

Conflicts of Interest: The authors declare no conflict of interest. Daegu-Gyeongbuk Medical Innovation Foundation had no role in the design of the study; in the collection, analyses, or interpretation of data; in the writing of the manuscript, or in the decision to publish the results.

\section{References}

1. Lux-Research. Nanomaterials State of the Market Q3 2008: Stealth Success, Broad Impact. Available online: https://portal.luxresearchinc.com/research/document_excerpt/3735 (accessed on 1 July 2008).

2. Chun, A.L. Will the public swallow nanofood? Nat. Nanotechnol. 2009, 4, 790-791. [CrossRef]

3. Hristozov, D.R.; Gottardo, S.; Critto, A.; Marcomini, A. Risk assessment of engineered nanomaterials: A review of available data and approaches from a regulatory perspective. Nanotoxicology 2012, 6, 880-898. [CrossRef]

4. Könczöl, M.; Ebeling, S.; Goldenberg, E.; Treude, F.; Gminski, R.; Gieré, R.; Grobéty, B.; Rothen-Rutishauser, B.; Merfort, I.; Mersch-Sundermann, V. Cytotoxicity and genotoxicity of size-fractionated iron oxide (magnetite) in A549 human lung epithelial cells: Role of ROS, JNK, and NF-kB. Chem. Res. Toxicol. 2011, 24, 1460-1475. [CrossRef]

5. Fubini, B.; Ghiazza, M.; Fenoglio, I. Physico-chemical features of engineered nanoparticles relevant to their toxicity. Nanotoxicology 2010, 4, 347-363. [CrossRef]

6. Cho, W.S.; Kang, B.C.; Lee, J.K.; Jeong, J.; Che, J.H.; Seok, S.H. Comparative absorption, distribution, and excretion of titanium dioxide and zinc oxide nanoparticles after repeated oral administration. Part. Fibre Toxicol. 2013, 10, 9. [CrossRef] [PubMed] 
7. Warheit, D.B.; Webb, T.R.; Sayes, C.M.; Colvin, V.L.; Reed, K.L. Pulmonary instillation studies with nanoscale $\mathrm{TiO}_{2}$ rods and dots in rats: Toxicity is not dependent upon particle size and surface area. Toxicol. Sci. 2006, 91, 227-236. [CrossRef] [PubMed]

8. Kim, S.; Choi, J.E.; Choi, J.; Chung, K.H.; Park, K.; Yi, J.; Ryu, D.Y. Oxidative stress-dependent toxicity of silver nanoparticles in human hepatoma cells. Toxicol. In Vitro 2009, 23, 1076-1084. [CrossRef]

9. Raghunathan, V.K.; Devey, M.; Hawkins, S.; Hails, L.; Davis, S.A.; Mann, S.; Chang, I.T.; Ingham, E.; Malhas, A.; Vaux, D.J.; et al. Influence of particle size and reactive oxygen species on cobalt chrome nanoparticle-mediated genotoxicity. Biomaterials 2013, 34, 3559-3570. [CrossRef] [PubMed]

10. Hackenberg, S.; Scherzed, A.; Technau, A.; Kessler, M.; Froelich, K.; Ginzkey, C.; Koehler, C.; Burghartz, M.; Hagen, R.; Kleinsasser, N. Cytotoxic, genotoxic and pro-inflammatory effects of zinc oxide nanoparticles in human nasal mucosa cells in vitro. Toxicol. In Vitro 2011, 25, 657-663. [CrossRef] [PubMed]

11. Magaye, R.; Zhao, J.; Bowman, L.; Ding, M. Genotoxicity and carcinogenicity of cobalt-, nickel- and copper-based nanoparticles. Exp. Ther. Med. 2012, 4, 551-561. [CrossRef]

12. Merget, R.; Bauer, T.; Küpper, H.U.; Philippou, S.; Bauer, H.D.; Breitstadt, R.; Bruening, T. Health hazards due to the inhalation of amorphous silica. Arch. Toxicol. 2002, 75, 625-634. [CrossRef] [PubMed]

13. Sandberg, W.J.; Låg, M.; Holme, J.A.; Friede, B.; Gualtieri, M.; Kruszewski, M.; Schwarze, P.E.; Skuland, T.; Refsnes, M. Comparison of non-crystalline silica nanoparticles in IL-1 $\beta$ release from macrophages. Part. Fibre Toxicol. 2012, 9, 32. [CrossRef] [PubMed]

14. Duncan, T.V. Applications of nanotechnology in food packaging and food safety: Barrier materials, antimicrobials and sensors. J. Colloid Interface Sci. 2011, 363, 1-24. [CrossRef] [PubMed]

15. Uboldi, C.; Giudetti, G.; Broggi, F.; Gilliland, D.; Ponti, J.; Rossi, F. Amorphous silica nanoparticles do not induce cytotoxicity, cell transformation or genotoxicity in Balb/3T3 mouse fibroblasts. Mutat. Res. 2012, 745, 11-20. [CrossRef]

16. Ahamed, M. Silica nanoparticles-induced cytotoxicity, oxidative stress and apoptosis in cultured A431 and A549 cells. Hum. Exp. Toxicol. 2013, 32, 186-195. [CrossRef]

17. Foldbjerg, R.; Wang, J.; Beer, C.; Thorsen, K.; Sutherland, D.S.; Autrup, H. Biological effects induced by BSA-stabilized silica nanoparticles in mammalian cell lines. Chem. Biol. Interact. 2013, 204, 28-38. [CrossRef]

18. Tan, X.; Liu, X.; Zhang, Y.; Zhang, H.; Lin, X.; Pu, C.; Gou, J.; He, H.; Yin, T.; Zhang, Y.; et al. Silica nanoparticles on the oral delivery of insulin. Expert Opin. Drug Deliv. 2018, 15, 805-820. [CrossRef]

19. Ryu, H.J.; Seong, N.W.; So, B.J.; Seo, H.S.; Kim, J.H.; Hong, J.S.; Park, M.K.; Kim, M.S.; Kim, Y.R.; Cho, K.B.; et al. Evaluation of silica nanoparticle toxicity after topical exposure for 90 days. Int. J. Nanomed. 2014, 9, 127-136. [CrossRef]

20. Guichard, Y.; Fontana, C.; Chavinier, E.; Terzetti, F.; Gaté, L.; Binet, S.; Darne, C. Cytotoxic and genotoxic evaluation of different synthetic amorphous silica nanomaterials in the V79 cell line. Toxicol. Ind. Health 2016, 32, 1639-1650. [CrossRef]

21. Good Laboratory Practice Regulation for Non-Clinical Laboratory Studies; Notification no. 2005-79; Ministry of Food and Drug Safety (MFDS): Cheongju, Korea, 2005.

22. Matesic, D.F.; Rupp, H.L.; Bonney, W.J.; Ruch, R.J.; Trosko, J.E. Changes in gap-junction permeability, phosphorylation, and number mediated by phorbol ester and non-phorbol-ester tumor promoters in rat liver epithelial cells. Mol. Carcinog. 1994, 10, 226-236. [CrossRef]

23. Hofer, A.; Sáez, J.C.; Chang, C.C.; Trosko, J.E.; Spray, D.C.; Dermietzel, R. C-erbB2/neu transfection induces gap junctional communication incompetence in glial cells. J. Neurosci. 1996, 16, 4311-4321. [CrossRef] [PubMed]

24. Trosko, J.E.; Ruch, R.J. Gap junctions as targets for cancer chemoprevention and chemotherapy. Curr. Drug Targets 2002, 3, 465-482. [CrossRef] [PubMed]

25. Mesnil, M.; Crespin, S.; Avanzo, J.L.; Zaidan-Dagli, M.L. Defective gap junctional intercellular communication in the carcinogenic process. Biochim. Biophys. Acta 2005, 1719, 125-145. [CrossRef] [PubMed]

26. Nimlamool, W.; Andrews, R.M.; Falk, M.M. Connexin43 phosphorylation by PKC and MAPK signals VEGF-mediated gap junction internalization. Mol. Biol. Cell 2015, 26, 2755-2768. [CrossRef]

27. OECD. OECD Guideline for Testing of Chemicals, Test. No. 471: Bacterial Reverse Mutation Test; OECD: Paris, France, 1997.

28. OECD. OECD Guideline for Testing of Chemicals, Test. No. 473: In Vitro Mammalian Chromosome Aberration Test; OECD: Paris, France, 1997. 
29. OECD. OECD Guideline for Testing of Chemicals, Test. No. 474: Mammalian Erythrocyte Micronucleus Test; OECD: Paris, France, 1997.

30. Heddle, J.A.; Stuart, E.; Salamone, M.F. The Bone Marrow Micronucleus Test in Handbook of Mutagenicity Test Procedures; Kilbey, B.J., Legator, M., Nichols, W., Ramel, C., Eds.; Elsevier: Amsterdam, The Netherlands, 1984; pp. 441-457.

31. Singh, N.P.; McCoy, M.T.; Tice, R.R.; Schneider, E.L. A simple technique for quantitation of low levels of DNA damage in individual cells. Exp. Cell Res. 1988, 175, 184-191. [CrossRef]

32. Olive, P.L.; Banáth, J.P.; Durand, R.E. Heterogeneity in radiation-induced DNA damage and repair in tumor and normal cells measured using the "comet" assay. Radiat. Res. 1990, 122, 86-94. [CrossRef]

33. Strober, W. Trypan blue exclusion test of cell viability. Curr. Protoc. Immunol. 2001, 161, 351-354. [CrossRef]

34. Babica, P.; Sovadinová, I.; Upham, B.L. Scrape Loading/Dye Transfer Assay. Methods Mol. Biol. 2016, 1437, 133-144. [CrossRef]

35. Kaszuba, M.; Connah, M.T. Protein and Nanoparticle Characterisation Using Light Scattering Techniques. Part. Part. Syst. Charact. 2006, 23, 193-196. [CrossRef]

36. Antonio Alves Júnior, J.; Baptista Baldo, J. The Behavior of Zeta Potential of Silica Suspensions. New J. Glass Ceram. 2014, 4, 29-37. [CrossRef]

37. Alkilany, A.M.; Mahmoud, N.N.; Hashemi, F.; Hajipour, M.J.; Farvadi, F.; Mahmoudi, M. Misinterpretation in Nanotoxicology: A Personal Perspective. Rev. Chem. Res. Toxicol. 2016, 29, 943-948. [CrossRef] [PubMed]

38. Laaksonen, T.; Santos, H.; Vihola, H.; Salonen, J.; Riikonen, J.; Heikkila, T.; Peltonen, L.; Kumar, N.; Murzin, D.Y.; Lehto, V.; et al. Failure of MTT as a toxicity testing agent for mesoporous silicon microparticles. Chem. Res. Toxicol. 2007, 20, 1913-1918. [CrossRef] [PubMed]

39. Medina-Ramírez, I.E.; Díaz de León Olmos, M.A.; Muñoz Ortega, M.H.; Zapien, J.A.; Betancourt, I.; Santoyo-Elvira, N. Development and Assessment of Nano-Technologies for Cancer Treatment: Cytotoxicity and Hyperthermia Laboratory Studies. Cancer Investig. 2020, 38, 61-84. [CrossRef] [PubMed]

40. Coleman, W.B.; McCullough, K.D.; Esch, G.L.; Faris, R.A.; Hixson, D.C.; Smith, G.J.; Grisham, J.W. Evaluation of the differentiation potential of WB-F344 rat liver epithelial stem-like cells in vivo. Differentiation to hepatocytes after transplantation into dipeptidylpeptidase-IV-deficient rat liver. Am. J. Pathol. 1997, 151, 353-359.

41. Guo, Y.; Martinez-Williams, C.; Gilbert, K.A.; Rannels, D.E. Inhibition of gap junction communication in alveolar epithelial cells by 18alpha-glycyrrhetinic acid. Am. J. Physiol. 1999, 276, L1018-L1026. [CrossRef]

42. Leithe, E.; Rivedal, E. Ubiquitination and down-regulation of gap junction protein connexin-43 in response to 12-O-tetradecanoylphorbol 13-acetate treatment. J. Biol. Chem. 2004, 279, 50089-50096. [CrossRef]

43. Kim, J.Y.; Yun, J.W.; Kim, Y.S.; Kwon, E.; Choi, H.J.; Yeom, S.C.; Kang, B.C. Mutagenicity and tumor-promoting effects of Tiglium seed extract via PKC and MAPK signaling pathways. Biosci. Biotechnol. Biochem. 2015, 79, 374-383. [CrossRef]

44. Jaganathan, H.; Godin, B. Biocompatibility assessment of Si-based nano- and micro-particles. Adv. Drug Deliv. Rev. 2012, 64, 1800-1819. [CrossRef]

45. Yu, K.O.; Grabinski, C.M.; Schrand, A.M.; Murdock, R.C.; Wang, W.; Gu, B.H.; Schlager, J.J.; Hussain, S.M. Toxicity of amorphous silica nanoparticles in mouse keratinocytes. J. Nanopart. Res. 2009, 11, 15-24. [CrossRef]

46. Park, E.J.; Park, K. Oxidative stress and pro-inflammatory responses induced by silica nanoparticles in vivo and in vitro. Toxicol. Lett. 2009, 184, 18-25. [CrossRef]

47. Kim, H.W.; Ahn, E.K.; Jee, B.K.; Yoon, H.K.; Lee, K.H.; Lim, Y. Nanoparticulate-induced toxicity and related mechanism in vitro and in vivo. J. Nanopart. Res. 2009, 11, 55-65. [CrossRef]

48. Li, Y.; Sun, L.; Jin, M.; Du, Z.; Liu, X.; Guo, C.; Li, Y.; Huang, P.; Sun, Z. Size-dependent cytotoxicity of amorphous silica nanoparticles in human hepatoma HepG2 cells. Toxicol. In Vitro 2011, 25, 1343-1352. [CrossRef]

49. Guo, C.; Wang, J.; Yang, M.; Li, Y.; Cui, S.; Zhou, X.; Li, Y.; Sun, Z. Amorphous silica nanoparticles induce malignant transformation and tumorigenesis of human lung epithelial cells via P53 signaling. Nanotoxicology 2017, 11, 1176-1194. [CrossRef]

50. Xie, D.; Zhou, Y.; Luo, X. Amorphous silica nanoparticles induce tumorigenesis via regulating ATP5H/SOD1-related oxidative stress, oxidative phosphorylation and EIF4G2/PABPC1-associated translational initiation. Peer] 2019, 7, e6455. [CrossRef] [PubMed]

51. Maron, D.M.; Ames, B.N. Revised methods for the mutagenicity test. Mutat. Res. 1983, 113, 173-215. [CrossRef] 
52. Hakura, A.; Suzuki, S.; Satoh, T. Advantage of the use of human liver S9 in the Ames test. Mutat. Res. 1999, 438, 29-36. [CrossRef]

53. Kaleeswaran, S.; Sriram, P.; Prabhu, D.; Vijayakumar, C.; Mathuram, L.N. Anti- and pro-mutagenic effects of silymarin in the Ames bacterial reverse mutation assay. Phytother. Res. 2009, 23, 1378-1384. [CrossRef] [PubMed]

54. Lee, M.Y.; Seo, C.S.; Kim, J.Y.; Shin, H.K. Evaluation of a water extract of So-Cheong-Ryong-Tang for acute toxicity and genotoxicity using in vitro and in vivo tests. BMC Complement. Altern. Med. 2015, 15, 235. [CrossRef]

55. Ishidate, M., Jr.; Sofuni, T. The in vitro chromosomal aberration test using Chinese hamster lung (CHL) fibroblast cells in culture. Prog. Mutat. Res. 1985, 5, 427-432.

56. Aky1l, D.; Konuk, M. Detection of genotoxicity and mutagenicity of chlorthiophos using micronucleus, chromosome aberration, sister chromatid exchange, and Ames tests. Environ. Toxicol. 2015, 30, 937-945. [CrossRef]

57. Landsiedel, R.; Kapp, M.D.; Schulz, M.; Wiench, K.; Oesch, F. Genotoxicity investigations on nanomaterials: Methods, preparation and characterization of test material, potential artifacts and limitations-many questions, some answers. Mutat. Res. 2009, 681, 241-258. [CrossRef] [PubMed]

58. Doak, S.H.; Manshian, B.; Jenkins, G.J.; Singh, N. In vitro genotoxicity testing strategy for nanomaterials and the adaptation of current OECD guidelines. Mutat. Res. 2012, 745, 104-111. [CrossRef]

59. Oesch, F.; Landsiedel, R. Genotoxicity investigations on nanomaterials. Arch. Toxicol. 2012, 86, 985-994. [CrossRef] [PubMed]

60. Woodruff, R.S.; Li, Y.; Yan, J.; Bishop, M.; Jones, M.Y.; Watanabe, F.; Biris, A.S.; Rice, P.; Zhou, T.; Chen, T. Genotoxicity evaluation of titanium dioxide nanoparticles using the Ames test and Comet assay. J. Appl. Toxicol. 2012, 32, 934-943. [CrossRef] [PubMed]

61. Grek, C.L.; Prasad, G.M.; Viswanathan, V.; Armstrong, D.G.; Gourdie, R.G.; Ghatnekar, G.S. Topical administration of a connexin43-based peptide augments healing of chronic neuropathic diabetic foot ulcers: A multicenter, randomized trial. Wound Repair Regen. 2015, 23, 203-212. [CrossRef] [PubMed]

62. Fukunaga, I.; Fujimoto, A.; Hatakeyama, K.; Aoki, T.; Nishikawa, A.; Noda, T.; Minowa, O.; Kurebayashi, N.; Ikeda, K.; Kamiya, K. In Vitro Models of GJB2-Related Hearing Loss Recapitulate $\mathrm{Ca}^{2+}$ Transients via a Gap Junction Characteristic of Developing Cochlea. Stem Cell Rep. 2016, 7, 1023-1036. [CrossRef] [PubMed]

63. Wu, D.; Zhao, J.; Wu, D.; Zhang, J. Ultraviolet A exposure induces reversible disruption of gap junction intercellular communication in lens epithelial cells. Int. J. Mol. Med. 2011, 28, 239-245. [CrossRef]

64. Berger, A.C.; Kelly, J.J.; Lajoie, P.; Shao, Q.; Laird, D.W. Mutations in Cx30 that are linked to skin disease and non-syndromic hearing loss exhibit several distinct cellular pathologies. J. Cell Sci. 2014, 127, 1751-1764. [CrossRef]

65. Willecke, K.; Eiberger, J.; Degen, J.; Eckardt, D.; Romualdi, A.; Güldenagel, M.; Deutsch, U.; Söhl, G. Structural and functional diversity of connexin genes in the mouse and human genome. Biol. Chem. 2002, 383, 725-737. [CrossRef]

66. Evans, W.H.; Martin, P.E. Gap junctions: Structure and function. Mol. Membr. Biol. 2002, 19, 121-136. [CrossRef]

67. Hayashi, Y. Overview of genotoxic carcinogens and non-genotoxic carcinogens. Exp. Toxicol. Pathol. 1992, 44, 465-471. [CrossRef]

68. Tacheau, C.; Laboureau, J.; Mauviel, A.; Verrecchia, F. TNF-alpha represses connexin43 expression in HaCat keratinocytes via activation of JNK signaling. J. Cell. Physiol. 2008, 216, 438-444. [CrossRef] [PubMed]

69. Tian, W.; Zhang, Z.; Cohen, D.M. MAPK signaling and the kidney. Am. J. Physiol. Renal Physiol. 2000, 279, F593-F604. [CrossRef]

70. Ueda, Y.; Hirai, S.; Osada, S.; Suzuki, A.; Mizuno, K.; Ohno, S. Protein kinase C activates the MEK-ERK pathway in a manner independent of Ras and dependent on Raf. J. Biol. Chem. 1996, 271, 23512-23519. [CrossRef] [PubMed]

71. Shen, K.; Novak, R.F. DDT stimulates c-erbB2, c-met, and STATS tyrosine phosphorylation, Grb2-Sos association, MAPK phosphorylation, and proliferation of human breast epithelial cells. Biochem. Biophys. Res. Commun. 1997, 231, 17-21. [CrossRef] [PubMed] 
72. Toyoda, M.; Suzuki, D.; Honma, M.; Uehara, G.; Sakai, T.; Umezono, T.; Sakai, H. High expression of PKC-MAPK pathway mRNAs correlates with glomerular lesions in human diabetic nephropathy. Kidney Int. 2004, 66, 1107-1114. [CrossRef] [PubMed]

73. Ariano, P.; Zamburlin, P.; Gilardino, A.; Mortera, R.; Onida, B.; Tomatis, M.; Ghiazza, M.; Fubini, B.; Lovisolo, D. Interaction of spherical silica nanoparticles with neuronal cells: Size-dependent toxicity and perturbation of calcium homeostasis. Small 2011, 7, 766-774. [CrossRef]

74. Yu, T.; Malugin, A.; Ghandehari, H. Impact of silica nanoparticle design on cellular toxicity and hemolytic activity. ACS Nano 2011, 5, 5717-5728. [CrossRef]

(C) 2020 by the authors. Licensee MDPI, Basel, Switzerland. This article is an open access article distributed under the terms and conditions of the Creative Commons Attribution (CC BY) license (http://creativecommons.org/licenses/by/4.0/). 